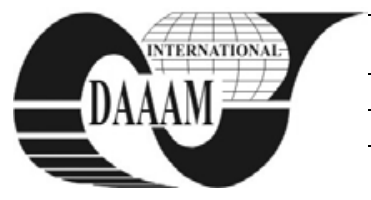

Annals of DAAAM for 2011 \& Proceedings of the 22nd International DAAAM Symposium, Volume 22, No. 1, ISSN $1726-9679$ ISBN 978-3-901509-83-4, Editor B. Katalinic, Published by DAAAM International, Vienna, Austria, EU, 2011 Make Harmony between Technology and Nature, and Your Mind will Fly Free as a Bird Annals \& Proceedings of DAAAM International 2011

\title{
A TAXONOMY OF SUPPORT SYSTEMS FOR CORPORATE GOVERNANCE
}

\author{
BRANDAS, C[laudiu]
}

\begin{abstract}
In literature and current studies there is a growing concern for the role of information systems and technology to ensure support for Corporate Governance (CG) process. For a better understanding the role of these technologies and systems to increase effectiveness and efficiency of CG, it would be necessary to analyze and classify them. This work paper is the result of a study on the typology of information systems and technologies used in GC in order to obtain taxonomy of support systems for Corporate Governance. That taxonomy allows understanding the role of each systems and technology in providing support for CG process and actors in order to increasing their effectiveness and efficiency.
\end{abstract}

Key words: corporate governance, support systems, taxonomy, decision-making, information systems

\section{INTRODUCTION}

In order to have all the conditions for good corporate governance, it is necessary to ensure information integrity and prevent abusive use of all information by all those involved in the internal or external governance system of the companies (Musson \& Jordan, 2005). In this context, the use of information technology (IT) can be viewed as a real support in order to ensure good corporate go-vernance (Lazarides \& Drimpetas, 2008). Information technologies could lead to an increase in efficiency for the corporate governance systems, by reducing information asymmetry within the agency relationship, offering a real and permanent support to the principal. Also, it could ensure increasing the efficiency of corporate governance systems, by ensuring support for monitoring and evaluating corporate governance in order to optimize and increase its performance (Kaplan \& Nagel, 2003).

In the literature we identified a series of systems and technologies used within corporate governance. They are focused on supporting only certain processes and are used in a dispersed way, so these systems and technologies cannot manage to create a sufficient transparency in order to decrease information asymmetry (Akerlof, Spence \& Stiglitz, 2001) and improve decision-making process.

By analyzing the systems and technologies that are used within the governance processes we develop a taxonomy of these systems according to their position within the company and their role in supporting corporate governance's process and actors.

\section{RESEARCH METHODOLOGY}

The research that has been done is based on an analytical study of the published works (articles and books) from 2001 to 2011 in the area of corporate governance, based on the following search key words: support systems in corporate governance, decision support systems and corporate governance, information technology and corporate governance. We extract data for our research from the following data bases:
ScienceDirect, ProQuest, Emerald, SpringerLink, Wiley Online Library and EBSCO.

\section{TAXONOMY OF THE SUPPORT SYSTEMS FOR CORPORATE GOVERNANCE (SSCG)}

As a result of our research, we obtained and propose a taxonomy of support systems for corporate governance. This taxonomy is based on an approach to systems and technologies in terms of intra-and extra- corporation. By this approach we want to locate and emphasize the role of each technology and systems inside and outside the corporation in correlation with all actors (shareholders, stakeholders, auditors, managers) in corporate governance systems.

Thus, we can classify them as follows:

A. Support systems and technologies for corporate governance from inside the com-pany:

1.The systems for supporting transactional processes and the tactical and operational management. Within this category we can include the ERP systems (Enterprise Resource Planning), SCM (Supply Chain Management) and CRM (Customer Relationships Management) (Hendricks et al., 2007). By analyzing the support offered to organiza-tional processes in the governance area, these systems offer an active and perma-nent support for processing transactions and disseminating information towards the management, auditors, clients and suppliers.

2.Systems for supporting communication and collaboration. Here we can mention the groupware systems and document management, and also the enterprise portals and the company websites (Jones, 2003), (Kelton \& Yang, 2008), (Jiang et al., 2009).

3.Systems and technologies for supporting decision-making process. In this category we can include the different decision support systems (DSS) for company man-agement (operational, strategic and tactical), BI technologies (Business Intelli-gence) and the hybrid intelligent systems (expert systems, intelligent agents, multi-agent systems) (Creamer \& Freund, 2010), (Streit \& Borenstein, 2009), (Filip, 2008). Considering the fact that the decision-making support in the governance processes uses financial reports, we can also in-clude XBRL language (Extensible Business Reporting Language) or XML in this category as a standard formula for representation and communication of the finan-cial reports (Alles \& Piechocki, 2010), (Roohani et al., 2009), (KPMG, 2008).

B.Support systems and technologies for corporate governance from outside the company: - in this category we can include the systems and technologies that offer an active support for presenting information and standards and also the codes of good practice (websites and dedicated information portals - OECD, ECGI, GMI, CGQ), re-spectively the information regarding the capital market evolution (informational portals for the stock market). Considering the communication of the financial reports with entities outside the company, we can include the XBRL or XML technology as a 
sup-port for financial data imports necessary for the decisionmaking process for corporate governance.

Starting with this taxonomy, in Table 1 we represented the way information systems and technologies ensure support for corporate governance actors inside and outside the corporation level. Summarizing the above, we can say that the Support Systems for Corporate Governance (SSCG) represent the assembly of systems and technologies for data and information processing and ensure transparency within corporate governance processes, respectively for monitoring and assessing it.

\begin{tabular}{|c|c|c|c|c|c|c|c|}
\hline & SSCG & Shareholders & Board of Directors & Managers & $\begin{array}{c}\text { Internal } \\
\text { Audit }\end{array}$ & $\begin{array}{c}\text { External } \\
\text { Audit }\end{array}$ & Stakeholders \\
\hline \multirow{7}{*}{ 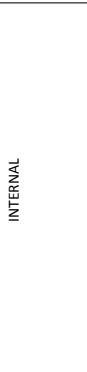 } & ERP, SCM, CRM & & & $x$ & $x$ & $x$ & \\
\hline & DSS & & & $x$ & & & \\
\hline & \begin{tabular}{|l|} 
Groupware \& \\
document \\
management
\end{tabular} & & $x$ & $x$ & $\mathrm{x}$ & & \\
\hline & Enterprise Portals & & $x$ & $x$ & $x$ & & \\
\hline & \begin{tabular}{|l|}
$\begin{array}{l}\text { Corporate's } \\
\text { Website }\end{array}$ \\
\end{tabular} & $\mathrm{x}$ & $x$ & $\mathrm{x}$ & & & $x$ \\
\hline & \begin{tabular}{|l|l} 
Intelligent \\
Support Systems
\end{tabular} & & $x$ & $x$ & $x$ & & \\
\hline & \begin{tabular}{|l|} 
Business \\
Intelligence \\
(OLAP, Data \\
mining)
\end{tabular} & & & $x$ & $x$ & $x$ & \\
\hline \multirow{2}{*}{ 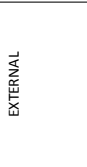 } & \begin{tabular}{|l|} 
Information \\
Portals (stock \\
exchange, OECD)
\end{tabular} & $x$ & $x$ & $x$ & $x$ & $x$ & $x$ \\
\hline & \begin{tabular}{|l|} 
Specialized \\
Websites (GMI, \\
OECD, ECGI, CGQ
\end{tabular} & $x$ & $x$ & $x$ & $x$ & $x$ & $x$ \\
\hline 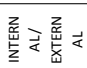 & XBRL, XML & $x$ & $x$ & $\mathrm{x}$ & $\mathrm{x}$ & $x$ & $x$ \\
\hline
\end{tabular}

Tab. 1. Actors and support systems for corporate governance

Analyzing Table 1 we can see that managers have access to resources from all technology and computer mainframe systems used inside or outside the organization. In this context the current way of organizing information systems in corporations do not reduce information asymmetry existing between the actors involved in corporate governance systems. Managers' access to these resources can be regarded as normal given their role in the corporation. But for a good corporate governance and reduction of information asymmetry is necessary that other actors can be shared and integrated access to these technologies and systems. In terms of technologies and systems we can say that the biggest support are offered, from outside of corporations, by information portals (of stock exchange, of OECD) and specialized websites (OECD, ECGI, GMI, CGQ, S\&P GAMMA) and from inside of corporations by the corporate website or corporate portal. In this context we can say that an integration and correlation of internal and external information resources and technologies for support of corporate governance system could be a first step towards increasing the effectiveness and efficiency of governance in the context of reducing information asymmetry existing between the actors of corporate governance.

\section{CONCLUSION}

The information system of corporate governance is a very complex one, which involves a series of actors, decisionmaking and transactional processes, technologies, procedures and good practice codes. In order to ensure the efficiency and efficacy of corporate governance as a premise for increasing company's performance and consolidation their position on the capital market, it is necessary to analyze the way information technology could contribute to this undertaking. Taxonomy of support systems for Corporate Governance discussed in this paper allows us to identify and analyze how technologies and systems can be integrated to offer shared support to all actors of corporate governance system. Through such an approach can be reduced both information asymmetry and can be improved effectiveness and efficiency of corporate governance systems.

As a future research the taxonomy of the support systems for corporate governance can constitute the starting point for creating a hybrid and adaptive support system for decision making for assessing and increasing corporate governance performance and also company performance. By implementing a decision support system focused on corporate governance necessities, that would integrate systems and technologies from inside and outside the company and offer decision making support in a collaborative manner to all actors of corporate governance, an efficiency and efficacy could be reached in corporate governance.

\section{ACKNOWLEDGEMENTS}

This paper is part of the research project POSDRU/89/1.5/S/59184 "Performance and excel-lence in postdoctoral research within the field of economic sciences in Romania", Babeş-Bolyai University, Cluj-Napoca being a partner within the project.

\section{REFERENCES}

Akerlof, G.A.; Spence, A.M. \& Stiglitz, J.E. (2001) Markets with Asymmetric Information, Com-mittee, Nobel Prize.

Alles, M. \& Piechocki, M. (2010). Will XBRL improve corporate governance?: A framework for enhancing governance decision making using interactive data, International Journal of Accounting Information Systems, In Press, Corrected Proof, Available online 30 October 2010, DOI: 10.1016/j.accinf.2010.09.008.

Creamer, G. \& Freund, Y. (2010). Learning a board Balanced Scorecard to improve corporate per-formance, Decision Support Systems, 49(4), pp. 365 - 385.

Filip, F.G. (2008). Decision support and control for large-scale complex systems, Annual Re-views in Control, 32, pp. 6170.

Hendricks, K.B.; Singhal, V.R. \& Stratman, J.K. (2007). The impact of enterprise systems on corporate performance: A study of ERP, SCM, and CRM system implementations, Journal of Operations Management, 25(1), pp. 65 - 82.

Jiang, Y.; Raghupathi, V. \& Raghupathi, W. (2009). WebBased Corporate Governance Infor-mation Disclosure: An Empirical Investigation, Information Resources Management Journal, 22(2), pp. 50 - 68

Jones, D. (2003). Corporate Governance Web page practices, The Corporate Governance Advisor, May/June, pp. 26-27.

Kaplan, R.S. \& Nagel, M.E. (2003). Improving Corporate Governance with the Balanced Scorecard, Working Paper, Harward Business School

Kelton, A.S. \& Yang, Y. (2008). The impact of corporate governance on Internet financial re-porting, Journal of Accounting and Public Policy, 27(1), pp. 62 - 87

Lazarides, T. \& Drimpetas, E. (2008). The missing link to an effective corporate governance system, Corporate Governance, 8(1), pp. 73-82

Musson, D. \& Jordan, E. (2005). The broken link: Corporate Governance and Information Technology, Australian Accounting Review, 15(3), pp. 11 - 19

Roohani, S.; Furusho, Y. \& Koizumi, M. (2009) XBRL: Improving transparency and monitoring functions of corporate governance, International Journal of Disclosure and Governance, 6(4), pp. 355-369

Streit, R.A. \& Borenstein, D. (2009). An agent-based simulation model for analyzing the go-vernance of the Brazilian Financial System, Expert Systems with Applications, 36, pp. 11489-11501

*** (2008) KPMG, Improving governance with XBRL, 2008.

*** (2004) OECD, Principles of Corporate Governance 